\title{
REFORMULASI SISTEM PENDIDIKAN PESANTREN DALAM MENGHADAPI GLOBALISASI DAN PASAR BEBAS
}

\author{
Zainal Efendi Hasibuan \\ Pascasarjana Program Magister Institut Agama Islam Negeri Padangsidimpuan \\ Jalan T. Rizal Nurdin KM. 4,5 Sihitang Padangsidimpuan \\ E-mail: zefendi60@yahoo.co.id
}

\begin{abstract}
Abstrak
Pesantren sebagai lembaga yang mempribumi diyakini sebagai lembaga yang tetap bisa eksis dalam menghadapi globalisasi dan pasar bebas. Pesantren memiliki fungsi memahamkan ilmu-ilmu agama dan membentuk akhlak mulia. Merespon perubahan zaman dalam konteks kekinian, pesantren perlu menentukan takhassusnya agar tidak terlalu sulit mendapatkan santri disebabkan semakin menjamurnya pondok pesantren di Indonesia; pesantren wajib mengajarkan life skill sesuai dengan kebutuhan daerah dan tuntutan masyarakat; pesantren perlu bekerjasama dengan berbagai pihak terkait untuk meningkatkan kualitas pendidikan pesantren; penguasaan bahasa Arab dan bahasa Inggris menjadi keharusan; pesantren perlu merumuskan visi, misi, tujuan, tujuan jangka pendek dan panjang, dan mengevaluasi setiap program kerja.
\end{abstract}

\begin{abstract}
Pesantren as society institutions is believed to be an institution that can still exist in the face of globalization and the free market. Pesantren has a function hang of religious sciences and formed a noble character. Responding to the changing times in the present context, schools need to determine takhassusnya that is not too difficult to get the students due to the proliferation of Islamic boarding schools in Indonesia; schools are required to teach life skills based on local needs and demands of society; schools need to work with various stakeholders to improve the quality of education schools; mastery of Arabic and English is a must; schools need to formulate a vision, mission, goals, short and long term objectives, and evaluate each work program.
\end{abstract}

Kata Kunci: Reformulasi, Pesantren, Globalisasi, Pasar bebas 


\section{Pendahuluan}

Pesantren merupakan kajian yang tidak pernah kering dibicarakan dan tetap hangat didiskusikan di pentas akademisi dan praktisi pendidikan terutama bila dikaitkan dengan globalisasi dan pasar bebas. Ada beberapa pertimbangan mengapa topik reformulasi sistem pendidikan pesantren dalam era globalisasi dan pasar bebas perlu diangkatkan. Pertama, pesantren merupakan lembaga pendidikan Islam tradisional yang tetap eksis namanya sampai sekarang, ketika nama lembaga-lembaga pendidikan tradisional lainnya tergerus seiring dengan lintasan zaman, seperti menunasah, rangkang, dayah dan surau. Kedua, globalisasi dan pasar bebas merupakan adalah hasil pemikiran kaum elit politik dan ekonom liberal, yang biasnya berpengaruh signifikan terhadap budaya lokal dan pola hidup manusia ketimuran, yang mengarah kepada westernisasi, materialisasi, dan hedonisasi. Ketiga, globalisasi dan pasar bebas memaksa jarum kompas pendidikan dari pendidikan berbasis pengembangan ilmu pengetahuan an sich menjadi berbasis life skill, mengubah paradigma pendidikan dari mendidik manusia menjadi ilmuwan menjadi manusia siap kerja, mengubah paradigma pesantren dari tafaqqah fi al-din menjadi lembaga bisnis. Keempat, pesantren merupakan lembaga pendidikan Islam yang sudah menyejarah di Indonesia, namun masih banyak persoalan yang dihadapinya, terutama bila dihadapkan dengan tuntutan globalisasi dan pasar bebas. Kelima, era globalisasi bukan saja mendatangkan pengaruh positif bagi dunia pendidikan, akan tetapi memberikan pengaruh negatif, terutama bagi negara yang belum siap menyambut era pasar bebas dan globalisasi.

Berdasarkan latar belakang di atas, penulis merangkai bangunan pondok pesantren yang siap tanding dalam menghadapi era globalisasi dan pasar bebas. Makalah ini terdiri dari beberapa pokok pembahasan: 1) hakekat dan asal usul pesantren, 2) makna globalisasi dan pasar bebas, 3) pesantren dalam menghadapi globalisasi dan pasar bebas.

\section{Hakekat dan Sekilas Perkembangan Pondok Pesantren}


Pondok pesantren berasal dari kata pondok dan pesantren. Pondok berasal dari pengertian asrama-asrama para santri yang disebut pondok atau tempat tinggal yang dibuat dari bambu, atau barangkali berasal dari kata Arab fundū q, yang berarti hotel atau asrama. ${ }^{1}$ Dengan demikian pondok adalah tempat tinggal dan penginapan bagi santri yang berfungsi di antaranya sebagai tempat istirahat, tempat makan, dan tempat belajar. Sementara pesantren berasal dari kata santri, yang dengan awalan pe dan akhiran an berarti tempat tinggal para santri. A.H Johns berpendapat bahwa istilah santri berasal dari bahasa Tamil, yang berarti guru mengaji, ${ }^{2}$ sedang C.C. Berg berpendapat bahwa istilah tersebut berasal dari shastri yang dalam bahasa India berarti orang yang tahu buku-buku agama Hindu, atau seorang sarjana ahli kitab suci Agama Hindu. Kata Shastri berasal dari kata shastra yang berarti buku-buku suci, buku-buku agama atau buku-buku tentang ilmu pengetahuan. ${ }^{3}$

Masuknya Islam ke Indonesia, tidak serta merta menghancurkan peninggalan-peninggalan Hindu dan Buddha, seperti tempat peribadatan, istilah-istilah, dan adat-istiadat. Islam masuk secara damai dengan pendekatan budaya masyarakat. Istilah pesantren sebagai lembaga pendidikan Islam, sehingga pesantren merupakan sebuah lembaga pendidikan Islam yang tetap mempribumi dan berkarakter khas Indonesia, diistilahkan dengan indegenous. ${ }^{4}$ Dalam perkembangan selanjutnya, pesantren menjadi lembaga yang konsen tafaqqah fi al-din, pembentukan

'Zamakhsyari Dhofier, Tradisi Pesantren; Studi tentang Pandangan Hidup Kyai (Jakarta: LP3ES, 1985), hlm. 18.

${ }^{2}$ A.H Johns, Rom Coastal Settlement to Islamic School and City: Islamization in Sumatra, the Malay Paninsula and Java, "dalam J. Fox (ed), Indonesia: The Making of a Culture (Canberra: R.S.P.S., A.N.U, 1980), hlm. 40.

${ }^{3}$ C.C. Berg, "Indonesia," dalam HLM.A.R. Gibb (ed). Whiter Islam; A Survey of Modern Movement in The Moslem World (London: 1932), hlm. 257.

${ }^{4}$ Mastuhu, Dinamika Sistem Pendidikan Pondok Pesantren (Jakarta INIS: 1994), hlm. 3 
akhlak mulia, mencetak kader-kader ulama masa depan, ${ }^{5}$ mengajarkan ilmu agama sekaligus mengamalkannya sebagai pola dan pedoman hidup, menjadi lembaga pendidikan unik yang langsung dipimpin oleh kyai sebagai pigur sentral. Pesantren memiliki kultur yang unik dengan elemen utama sebagai subkultur, yakni pola kepemimpinan yang berada di luar kepemimpinan pemerintahan desa, literatur universalnya terus terpelihara selama berabad-abad yang diikuti masyarakat luas. ${ }^{6}$ Secara paedagogis pesantren merupakan lembaga pendidikan tradisional Islam yang bertujuan untuk memahami, menghayati, dan mengamalkan ajaran Islam. ${ }^{7}$

Pada masa pemerintahan Hindia Belanda, akibat perlawanan yang dilakukan kaum santri dan kekhawatiran pihak Belanda, diberlukan peraturan ordonansi pendidikan. Sehingga banyak banyak pesantren yang ditutup. Sehingga pesantren yang tidak memenuhi syarat, tidak boleh dibuka. Selanjutnya menjelang kemerdekaan, banyak pesantren yang berubah status menjadi madrasah, lebih-lebih lagi lembaga-lembaga pendidikan di luar Jawa, seperti surau di Sumatera Barat, dayah di Aceh, dan rangkang di Kalimantan banyak yang berubah nama menjadi madrasah.

Pada masa Orde Lama tidak begitu banyak perubahan pada pesantren. Pada masa Orde Baru, terutama tahun 1975 dikeluarkan SKB 3 Menteri, yakni Menteri Pendidikand dan Kebudyaan, Menteri Agama, dan Manteri Dalam Negeri, merupakan moment yang paling bersejarah terkait dengan legalitas ijajah dan alum pesantren dapat melanjutkan pendidikannya ke Perguruan Tinggi Umum (PTU). Dari satu sisi sangat menguntungkan namun di sisi lain melemahkan, konsistensi pesantren sebagai lembaga pendidikan tafaqgh fi al-din mulai kehilangan gairahnya dan kehilangan titik nadirnya. Paduan antara ilmu-ilmu umum dengan ilmuilmu agama, mengakibatkan banyaknya alumni pesantren yang dangkal

${ }^{5}$ Tidjani Djauhari, Masa Depan Pesantren Agenda yang Belum Terselesaikan (Jakarta, Publishing, 2008.) hlm. Ix.

${ }^{6}$ Abdurrahman Wahid, Menggerakkan Tradisi Esai-esai Pesantren Mogyakarta: LKiS, 2001) hlm. 171.

${ }^{7}$ Nurcholish Madjid, Bilik-bilik Pesantren Sebuah Potret Perjalanan (Jakarta, Paramadina 1997), hlm. 107. 
ilmu agamanya dan dangkal ilmu umumnya, terutama lembaga pendidikan pesantren yang lemah manajemennya.

Pada Era Reformasi, ada banyak perubahan pada sistem negara, yakni otonomi daerah dan desentralisasi, disambut tantangan eksternal berupa globalisasi dan pasar bebas. Tantangan ini berpengaruh terhadap sistem pendidikan pesantren.Pesantren yang tidak berbenah diri dan tidak siap tampil pada gelanggang perubahan zaman, banyak yang ditinggalkan dan tidak diminati masyarakat. Orang tua tidak "PD" memasukkan anaknya ke pesantren yang "kalah saing". Sebaliknya, pesantren yang terus berbenah diri, adaptif, dan kompetitif orang tua banyak terobsesi dan memiliki minat tinggi untuk memasukkan anaknya ke pesantren tersebut. Tipikal pesantren yang menjadi dambaan orang tua adalah pesantren yang memiliki keunikan, takhassus, distingsi, diantaranya: pesantren yang bertakhassus mahir bahasa Arab dan dan bahasa Inggris, pesantren bertakhassus al-Qur'an (hafis al-Qur'an), pesantren yang bertakhussus life skiil (keterampilan), pesantren yang alumninya menembus perguruan tinggi luar negeri, pesantren yang memenangkan sains pada berbagai olimpiade atau bertakhssus di bidang sains, pesantren santrinya sering juara pada MTQ tingkat Nasional dan internasional, pesantren yang alumninya banyak yang duduk di Jabatan Politik dan Pemerintahan, pesantren yang menggeratiskan biaya pendidikan.

\section{Makna Globalisasi dan Pasar Bebas}

Globalisasi sering diterjemahkan "mendunia" atau "mensejagat". Globalisasi berasal dari kata "the globe"(Inggris) atau "la monde" (Prancis) yang berarti bummi, dunia ini. Maka "globalisasi" atau "mondialisation" secara sederhana dapat diartikan sebagai proses menjadikan semuannya satu bumi atau satu dunia. ${ }^{9}$ Globalilasi berasal dari kata globe, merupakan

\footnotetext{
${ }^{8}$ Ahmad Arifi, Politik Pendidikan Islam: Menelusuri Ideologi dan Aktualisasi Pendidikan Islam di Tengah Arus Globalisasi, (Yogyakarta, Teras, 2010), hlm. 140

9 Imam Machali, Musthofa, Pendidikan Islam dan Tantangan Globalisasi: Buah Pikiran Seputar; Filsafat, Politik, Ekonomi, Sosial, dan Budaya, (Yogyakarta: PRESMA, 2004), hlm. 109.
} 
miniatur dari bumi, atau bumi dalam ukuran bola kaki. Secara sederhana globalisasi adalah tidak adanya pembatas teriteorial dalam mengakses informasi, dalam hitungan detik informasi dari luar negeri dapat diterima. Globalisasi adalah intensifikasi hubungan sosial sejagat yang menghubungkan tempat-tempat yang berjauhan sedemikian rupa, sehingga peristiwa lokal bisa terjadi disebabkan oleh kejadian ditempat lain yang sekian mil jauhnya dan sebaliknya.

Pasar bebas (free trade) adalah perdagangan dengan gaya baru yang dihasilkan oleh globalisasi, para pebisnis dan pedagang luar negeri bebas memasarkan barang dagangannya di Indonesia, demikian sebaliknya. Ekonomi merupakan salah satu tuntutan dan kebutuhan manusia dalam berkompetisi di ajang dunia ASEAN dan internasional. Beberapa gagasan muncul dalam menyambut dan menghadapi globalisasi dan pasar bebas. Negara-negara ASEAN telah menyepakati Asean Free Trade Agrement disingkat dengan AFTA, telah ditetapkan tahun 2003. ASEAN Economic Community (AEC) yang direncanakan akan tercapai pada tahun 2015, dikenal dengan Masyarakat Ekonomi ASEAN (MEA). Dengan adanya AEC ini, diharapkan akan terjadi peningkatan arus barang, jasa, investasi, tenaga yang terampil dan aliran modal antar negara di Asia Tenggara sehingga nantinya dapat meningkatkan daya saing di pasar dunia. Lahir juga kesepakatan pasar bebas di negara Asia-Pasific, yang terkenal dengan Asian Pasific Economic Coorporation (APEC) berlaku pada tahun 2020. Belahan dunia Eropa, lahir integrasi ekonomi disebut European Union (EU), di Amerika Utara dibentuk Nort American Free Trade Area (NAFTA). ${ }^{10}$

Dalam konteks kekinian, yakni globalisasi dan pasar bebas, pendidikan Islam paling tidak menghadapi tiga persoalan esar, ${ }^{11}$ 1) banyak lembaga pendidikan Islam masih menggunakan cara-cara tradisional, baik dalam kepemimpinan, manajemen, kurikulum, dan pembelajaran, sehingga mengalami kesulitan untuk beradaptasi dan berkompetisi di era pasar bebas

${ }^{10}$ Abuddin Nata, Paradigma Baru Pendidikan Islam di Era Pasar Bebas, dalam Samsul Nizar, Reformulasi Pendidikan...hIm. 20.

${ }^{11}$ Ramayulis, Reaktualisasi Pendidikan Islam, dalam Samsul Nizar, Reaktualisasi Pendidikan...hIm. 109. 
dan globalisasi, 2) persoalan normatif-filosofis. Misalnya, tujuan pendidikan Islam adalah menciptakan manusia idel, yakni 'abdun shāalih, khaîifat $f i$ alardh, al-akh/āq al-karimah, dan al-insān al-kāmil. Akan tetapi bagaimana gambaran manusia tersebut masih diperdebatkan para pakar. Dalam persoalan lembaga pendidikan, apakah tipe madrasah yang harus dikembangkan, apakah tipe pesantren, atau sekolah umum berciri khas agama masih diperdebatkan, 3) persoalan klasik dan standar pendidikan, seperti kualitas guru yang belum memadai, sumber daya manusia dan dana, produktifitas lembaga yang kurang bermutu, sarana-prasarana yang tidak lengkap, perpustakaan yang tidak memadai, persoalan politik kepemimpinan yang mengalahkan pengembangan lembaga, kurikulum yang tidak tuntas.

\section{Pesantren dalam Menghadapi Globalisasi dan Pasar Bebas}

Pasantren sebagai lembaga pendidikan yang mempribumi tanah air, diharapkan mampu untuk membenahi diri untuk mencetak santri yang siap tampil beradaptasi sekaligus berkompetisi dalam menghadapi globalisasi dan pasar bebas. Fazlur Rahman mengatakan bahwa kemungkinan besar madrasah-madrasah dan pesantren-pesantren akan menjadi feeder Institution sumber in put bagi lembaga-lembaga Islam negeri. Nurcholish Madjid, sebagai dikutip Yasmadi, pesantren dimungkinkan sebagai sebagai lembaga pendidikan masa depan Indonesia. ${ }^{12}$ Dalam hal ini, tentunya pengelola pesantren wajib optimis, yakin bahwa pesantren dapat menjadi jawaban utama dalam tuntunan zaman kekinian.

Ada beberapa pokok pemikiran penulis, yang dapat dijadikan sebagai khazanah berpikir pengembangan pesantren masa depan yang diminati masyarakat dan menjadi solusi dalam menjawab tantangan zaman, sebagai berikut:

a. Kemampuan dalam merumuskan visi, misi, tujuan, rencana strategis, program jangka pendek dan program jangka panjang. Perumusan visi

${ }^{12}$ Yasmadi, Modernisasi Pesantren Kritik Nurcholis Madjid Terhadap Pesantren Islam Tradisional, (Jakarta: Ciputat Press, 2002), hlm. 3 
dan misi hendaknya membaca situasi terkini dan keunikan tersendiri yang dibutuhkan umat masa kini. Dalam ungkapan pengajuan usulan program studi di tingkat perguruan tinggi, disebut dengan distingsi Keunikan tersebut maknanya adalah ada yang khas, dari pesantren yang kita bangun, ada yang unggul dari pesantren yang kita bangun dibandingkan daripada pesantren lainnya, misalnya unggul dalam kemampuan membaca kitab kuning, unggul dalam bahasa Arab dan bahasa Inggris, unggul dalam hafiz al-Qur'an, unggul dalam sains, unggul dalam sastra, unggul di bidang hukum, unggul di bidang dakwah, unggul di bidang pertanian dan peternakan, unggul dalam life skill, dan keunggulan lainnya. Visi dan misi pendidikan harus dirancang sesuai dengan nilai-nilai ajaran Islam dan tuntutan globalisasi dan pasar bebas. Visi pendidikan Islam hendaknya berwawasan universal dan global, yakni visi rahmatan li al-âalamīn-wa ma arsalnā ka il/ā rahmatan li al-âmīn, sedangkan misi pendidikan terkait dengan misi kenabian dalam memberikan pencerahan umat menusia, yakni misi ti/â wah, tazkiyyah, dan misi ta'îm. Visi dan misi pendidikan Islam berisifat future oriented, memahami kecenderungan perubahan sosial, budaya, dan iklim politik dengan tetap mempertahankan identitas keislamannya sebagai ajaran yang sarat nilai, hasanah fi al-dunya wa hasanah fi al-akhirat wa qina 'adzab al-nar. Visimisi tersebut hendaknya mengilhami dan menjiwai seluruh komponenkomponen pendidik, mulai dari tujuan, kurikulum, guru, murid, proses pembelajaran, sarana-prasarana, biaya pendidikan, lingkungan dan evaluasi. Tujuan pendidikan pesantren, bagi Imam Zarkasyi, ${ }^{13}$ tujuan pendidikan di Gontor untuk menjadi orang...mengetahui apa yang dikerjakan di masayarakat, ringkasnya pendidikan kemasyarakatan.

b. Untuk menghadapi era globalisasi pesantren hendaknya menyiapkan santri yang menguasai kemampuan bahasa internasional, minimal bahasa Inggris dan bahasa Arab. Bahasa Inggris berguna sebagai bekal menggali ilmu-ilmu sains dan teknologi, alat beradaptasi, berkomunikasi dan berkompetisi pada gelanggang globalisasi dan perkembangan teknologi-

${ }^{13}$ Jajat Burhanuddin dan Ahmad Baidhowi, Transformasi Otoritas Keagamaan, (Jakarta: Gramedia Pustaka Utama, 2003), hlm. 145. 
informasi yang kebanyakan ditulis dengan menggunakan bahasa Inggris. Bahasa Arab berguna untuk memperdalam khazanah ilmu-ilmu keislaman, seperti tafsir, hadis, ushul figh, tasawuf, yang banyak ditulis dengan mnggunakan bahasa Arab. Tiga mahārat yang harus dimiliki dalam kajian bahasa, mahā rat al-takallum, mahā rat al-istimā', mahā rat al-kitābat, dan mahā rat al-qira'ah. Salah satu pesantren yang berhasil dalam mengajarkan bahasa Arab adalah Pondok Pesantren Gontor, bahasa Arab dan bahasa Inggris menjadi karakteristik lembaga pendidikannya. Pelajaran bahasa Arab lebih ditekankan kepada penguasaan kosa kata, sehingga para santri kelas satu sudah diajarkan mengarang dalam bahasa Arab dengan menggunakan kosa kata yang dimilikinya. Pelajaran ilmu alat seperti Nahu dan Sharaf diberikan ketika santri kelas II, yakni ketika sudah agak lancar berbicara dan memahami struktur kalimat. Sementara pelajaran balaghah diajarkan setelah kelas V. Bahasa Inggris, Grammar baru diajarkan ketika santri kelas III, sedangkan materi bahasanya sudah diajarkan sejak kelas I. ${ }^{14}$

c. Untuk menghadapi tantangan arus budaya asing yang masuk ke tanah air dan perubahan yang bakal terjadi, pendidikan Islam dalam menghadapi berbagai perubahan yang bakal terjadi, handaknya memiliki prinsip yang kuat dan kokoh, sehingga tidak terombang-ambing dan juga tidak kaku. Prinsip-prinsip tersebut seperti 1) prinsip tauhidisasi dan integralistik. Prinsip tauhidisasi adalah keyakinan bahwa ilmu apa pun yang dikembangkan, perlu diintegrasikan dengan keyakinan lā i/āha illa Al/āh, ilmu dari Allah SWT, milik Allah dan untuk pengabdian kepada Allah, 2) prinsip keterbukaan

Prinsip keterbukaan adalah bahwa Islam tidak menutup dirinya dengan perkembangan zaman, kemajuan ilmu pengetahuan dan teknologi, shalih likulli zamānin wa makānin, 3) prinsip keseimbangan, yakni keseimbangan dunia dan akhirat, keseimbangan akal, rasa, karsa, keseimbangan jasmani dan ruhani, keseimbangan materi dan immater

${ }^{14}$ Abuddin Nata, Pemikitran Para Tokoh Pendidikan Islam Seri Kajian Filsafat Pendidikan Islam, Jakarta: RajaGrfido Persada, 2003), cet. Ke-3, hlm. 206. 
serta kesimbangan ilmu dan amal, 4) prinsip kedinamisan dan fleksibilias, yakni terus melakukan reformasi dan reformulasi menuju kesempurnaan, tidak kaku dengan modernisasi dan tidak memelihara kebekuan ijtihad, 5) prinsip egaliter, yakni manusiswi dan demokratis, tidak membedakan jenis kelamin, ras, etnis, dan latar belakang status sosial, prinsip long life education, education for all, 6) prinsip rasionalitas dan keadilan, yakni menyerahkan urusan kepada ahlinya, bukan berdasarkan korupsi, kolusi, dan nopotisme, 7) prinsip universalitas, bahwa pendidikan Islam hendaknya mengambangkan seluruh dimensi dan cabang ilmu pengetahuan, tidak hanya mengkaji ilmu-ilmu yang sifatnya 'ubudiyah semata, 8) prinsip efisiensi dan efektivitas, yakni pendidikan Islam hendaknya memperhatikan waktu dan yang ada, mempergunakan waktu sebaik-baiknya, dan mengelola dana pendidikan secara proporsional dan profesional, 8) prinsip relevansi, bahwa kurikulum yang dikembangkan relevan dengan kebutuhan lokal/daerah dan kebutuhan masyarakat, sehingga out put pendidikan Islam dapat memberikan pencerahan dan bermenfaat di tengah-tengah masaraka.,

d. Reformasi dan reformulasi strategi pembelajaran. Model dan sistem pembelajaran perlu diubah dari sistem pembelajaran tradisional menuju pembelajaran situasional-kekinian tanpa meninggalkan sisi positif model dan sistem pembelajaran tradisonal, seperti dalam mengajarkan alQur'an dan hadis masih membutuhkan metode hafalan. Reformasi di bidang pembelajaran dapat dilakukan dengan cara mengubah pola pembelajaran teacher centere kepada student centere. Strategi pembelajaran pendidikan Islam perlu mengadaptasi model pembelajaran modern dan kekinian, seperti pembelajaran berbasis web (e-learning), model pembelajaran berbasis komputer, model pembelajaran Contextual Teaching and Learning (CTL), model pembelajaran tematik, model PAKEM (Partisipatif, Aktif, Kreatif, Efektif, dan Menyenangkan), dan model pembelajaran mandiri, problem base learning ( $\mathrm{PBL})$, cooperative learing $(\mathrm{CL})$, interactive learning $(\mathrm{IL})$, progressif learing $(\mathrm{Pl})$. Menggunakan metode variatif yang disesuaikan dengan kondisi dan situasi, melihat aspek perkembangan psikologis peserta didik, membaca keragaman 
intelektual, maka dapatlah digunakan metode ceramah, debat, dialog, tanya jawab, cerita, hadiah dan hukuman, pembiasaan, keteladanan, demonstrasi, dan eksperimen. Metode pembelajaran yang demikian, akan dapat menghilangkan kebosanan dan kejenuhan peserta didik.

e. Ketangguhan Mental. Ketangguhan mental adalah kemampuan seseorang dalam menghadapi berbagai keadaan situasi dan kondisi, keadaan, tantangan dalam kehidupan. Imam Zarkasyi merumuskan sikap mental yang tangguh yang disebut Panca Jiwa Pondok, yaitu keikhlasan, kesederhanaan, kesanggupan menolong diri sendiri, ukhwah Islamiyah dan jiwa bebas. ${ }^{15}$ Jiwa ikhlas yaitu sepi ing pamrih lillahi ta'ala. Jiwa kesederhanaan adalah sikap dan tutur kata yang tidak berlebih-lebihan, apa adanya tanpa merasa rendah diri. Jiwa kesanggupan menolong diri sendiri adalah kemandirian, tidak tergantung kepada orang lain. Jiwa ukhwah Islamiyah adalah sikap yang bersahabat dan akrab dengan sesama teman tanpa mengenal latar belakang perbedaaan status sosial. Jiwa bebas adalah sikap yang mersa bebas berpikir dan berbuat, bebas menentukan masa depan dan jalan hidupnya di masyarakat kelak, dengan jiwa besar dalam menghadapi berbagai tantangan. ${ }^{16}$

f. Menciptakan peserta didik yang unggul dan kompetitif. Tantangan globalisasi dan era pasar bebas menghendaki manusia yang memiliki kompetensi yang unggul dan dapat diandalkan, sehingga ia dapat bersaing dan memiliki rasa percaya diri. Manusia pada saat ini mau-tidak mau harus menjadi manusia pembelajar, siapa yang tidak mau menjadi manusia pembelajar kelak akan tergilas dan tinggal landas. Pembelajar yang baik adalah pembelajar yang memahami dan mengimplementasikan konsepsi learning to know, learning to do, learning to be, dan learning to life together. Dalam hal ini, posisi pendidik/guru berperan sebagai inspirator, katalisator, fasilitator dan motivator. Pembelajaran yang demikian akan menciptakan suasana

${ }^{15}$ Abuddin Nata, Tokoh-tokoh Pembaharuan Pendidikan Islam di Indonesia, (Jakarta: Rajawali Pers, 2005), cet. Ke-3, hlm. 211.

${ }^{16} /$ bid., hlm. 212. 
pembelajaran yang dinamis, kreatif, dan menyenangkan, yang akan melahirkan peserta didik yang cerdas dan tercerahkan. Paradigma belajar juga harus diubah, dari hafalan ke dialog dan penguasaan metodologi, dari pasif menjadi aktif heuristik, dari memiliki ke menjadi, dari mekanistik ke kreatif, Pendidikan hendaknya dirancang dengan prinsip demokrasi dan multikultural, hal ini dilakukan untuk mengurangi dan menghindari aliran ekstrimis dan radikalisme Islam di tengah kebhinnekaan tunggal ika.

g. Rekonstruksi kurikulum. Menurut UU No. 20/2003 tentang Sistem Pendidikan Nasional pasal 36 ayat (2), bahwa kurikulum pada semua jenjang dan jenis pendidikan dikembangkan dengan prinsip diversifikasi sesuai dengan satuan pendidikan, potensi daerah dan peserta didik. Dalam menghadapi era pasar bebas, pesantren membuka berbagai keahlian, seperti Perbengkelan, Teknik Industri, Pertanian, Perhotelan, Kepariwisataan, Penerbangan, Tata Boga, Seni, Perdagangan, Kedokteran, Kebidanan, Kimia, Fisika, Matematika, Pertambangan, Listrik, Astronomi, Otomotif, Perikanan, Budaya dan Antropologi, Politik, Tata Negara, Jurnalistik, dan lainnya. Khusus Tapanuli Selatan, dapat dibuka insdustri salak dan industri kopi, keparawisataan pertanian, dan pertambangan.

h. Menumbuhkan spirit dan motivasi pembelajaran dengan pendekatan fia ayi waqtin wa ainama takū nū, kapan di mana saja. Hal ini terlihat dari semangat studi pada masa keemasan Islam. Sejarah menginformasikan bahwa hampir setiap tempat tinggal dijadikan wadah atau lembaga pendidikan, mulai dari kuttab, masjid, shuffah, khan, bimaristan, almaktabat, al-madaris, majelis ulama, badiah, al-hawanit al-waruqin, observatorium, istana dan bahkan di rumah sakit dijadikan tempat studi. Pada kondisi perang belajar, apalagi dalam kondisi tenang. Mengembalikan zaman keemasan Islam hendaknya kembali menumbuhkan spirit pengembangan ilmu pengetahuan sebagaimana pada masa dinasti Abbasiyah.

i. Perlu adanya Laporan Pertangggungjawaban Prestasi (LPP) atau disebut juga akuntabilitas kerja. Laporan ini menjelaskan pelaksanaan pendidikan, baik dalam perekrutan tenaga kerja, penerimaan santri, pembelajaran, 
dan out-put. LPP hendaknya menggambarkan kualitas kinerja tenaga kependidikan dan kualitas alumni, sejauha mana keterpakaian alumni di masyarakat. Akuntabilitas ini disampaikan kepada pemerintah, masyarakat, dan stake kholders pemakai lulusan. Laporan tersebut akan menjadi bahan bagi stake kholders untuk menilai sejauhmana suatu lemabaga pendidikan telah berhasil melaksanakan proses pendidikan, dan instrumen penilaian bagi pengelola lembaga pendidikan untuk meningkatkan prestasi pendidikan di masa mendatang.

j. Pondok pesantren perlu melakukan kerjasama dengan pihak perguruan tinggi dan instansi terkait dengan takhasus yang dikembangkan. Kerjasama di sini, baik dalam hal peningkatan SDM dan tenaga kependidikan, pengembangan kurikulum, kerja sama riset, dan sebagainya. Oleh karena itu tujuan dan arah pengembangan pesantren masa depan diharapkan paling tidak mengacu pada tiga elemen penting; pertama : pola kepemimpinan pondok pesantren yang mandiri dan tidak terkooptasi oleh Negara, kedua: kitab-kitab rujukan harus relevan dengan konteks realitas yang berkembang pada saat ini, ketiga: sistem nilai (value system) yang digunakan adalah bagian dari masyarakat luas sebagai pengguna jasa dari out put pesantren. Dengan berbekal tiga elemen tersebut diharapkan pesantren dapat melakukan terobosan-terobosan baru bagaimana seharusnya pesntren yang refsentatif masa depan.

\section{Penutup}

Natijah yang dapat dikemukakan dari tulisan singkat ini adalah 1) harus Percaya Diri (PD) dalam menghadapi tantangan zaman, siapa cepat dia sukses siapa lambat dia tergilas, 2) pesantren berani tampil beda, memilih takhassus sesuai dengan kemampuan tenaga pendidik, kondisi iklim daerah setempat, dan kebutuhan pengguna (user out put pendidikan), 3) perlu perubahan dalam manajemen pendidikan, sistem pembelajaran, reogranisasi kurikulum, pembenahan sarana-prasarana pendidikan, 4) kerjasama dengan instansi pemerintah, Perguruan Tinggi, antar pesantren, Pengguna Lulusan, orang tua santri, lingkungan masyarakat, pakar pendidikan, perlu dijalin dengan baik terutama untuk merumuskan 
kurikulum, program pendidikan, dan takhassus pesantren, 5) bahasa Asing, terutama bahasa Arab dan bahasa Inggris perlu menjadi pokok perhatian, 6) life skiil, mental Islami, akhlak mulia adalah menjadi keharusan dalam menyiapkan santri yang siap tampil di pasar global dan pasar bebas.

\section{Daftar Pustaka}

Al-Ghazālī, Abī Hāmid Muhammad Ibn Muhammad, Ihyā' 'U/ūm al-Dĩn, Berut-Libnan: Dār al-Fikr, 1991.

Arifi, Ahmad, Politik Pendidikan Islam: Menelusuri Ideologi dan Aktualisasi Pendidikan Islam di Tengah Arus Globalisasi, Yogyakarta, Teras, 2010.

Berg, C.C., "Indonesia," dalam H.A.R. Gibb (ed). Whiter Islam; A Survey of Modern Movement in The Moslem World, London: 1932.

Burhanuddin, Jajat dan Ahmad Baidhowi, Transformasi Otoritas Keagamaan, Jakarta: Gramedia Pustaka Utama, 2003.

Delor, Jacues et.al. Learning: The Threasure Within, Report to UNESCO of the International Commision on Education the Twinty-first Century, Paris: Unesco Publishing, 1996.

Dhofier, Zamakhsyari, Tradisi Pesantren; Studi tentang Pandangan Hidup Kyai, Jakarta: LP3ES, 1985.

Djauhari, Tidjani, Masa Depan Pesantren Agenda yang Belum Terselesaikan, Taj Jakarta, Publishing, 2008.

Hasibuan, Zainal Efendi, Menyingkap Kiat Sukses Studi di Perguruan Tinggi, Medan: Mitra, 2012.

Imam Machali, Musthofa, Pendidikan Islam dan Tantangan Globalisasi: Buah Pikiran Seputar; Filsafat, Politik, Ekonomi, Sosial, dan Budaya, Yogyakarta: PRESMA, 2004.

Johns, A.H, Coastal Settlement to Islamic School and City: Islamization in Sumatra, the Malay Paninsula and Java, "dalam J. Fox (ed), Indonesia: The Making of a Culture, Canberra: R.S.P.S., A.N.U, 1980. 
Madjid, Nurcholish, Bilik-bilik Pesantren Sebuah Potret Perjalanan, Jakarta, Paramadina 1997.

Madjid, Nurcholish, Islam Agama Peradaban, Jakarta: Paramadina, 1995.

Mastuhu, Dinamika Sistem Pendidikan Pondok Pesantren. Jakarta INIS: 1994.

Nata, Abuddin, Paradigma baru Pendidikan Islam di Era Pasar Bebas, dalam

Samsul Nizar (ed.), Reformulasi Pendidikan Islam Menghadapi Era

Pasar Bebas, Jakarta: The Minangkabau Foundation, 2005.

Pendidikan Islam, Jakarta: RajaGrfido Persada, 2003.

--------------, Tokoh-tokoh Pembaharuan Pendidikan Islam di Indonesia, Jakarta: Rajawali Pers, 2005.

Ramayulis, Reaktualisasi Pendidikan Islam dalam Konteks Kekinian dan Kedisinian, dalam Samsul Nizar (ed.), Reformulasi Pendidikan Islam Menghadapi Era Pasar Bebas, Jakarta: The Minangkabau Foundation, 2005.

Sinamo, Jansen, Strategi Adaptif Abad ke-21: Berselancar di Atas Gelombang Krisis, Jakarta: PT Gramedia Pustaka Utama, 2000.

Wahid, Abdurrahman, Menggerakkan Tradisi Esai-esai Pesantren.Yogyakarta: LKiS, 2001.

Yasmadi, Modernisasi Pesantren Kritik Nurcholis Madjid Terhadap Pesantren Islam Tradisional.Jakarta: Ciputat Press, 2002. 